\title{
ANALISIS KONFLIK ANTARA MASYARAKAT DENGAN PERHUTANI AKIBAT PENGAMBILAN LAHAN KEHUTANAN
}

\author{
Fani Julia Putri ${ }^{1}$, Bunyamin Maftuh²,Elly Malihah ${ }^{3}$ \\ ${ }^{1}$ SMA Negeri 2 Cianjur \\ 2Dosen Program Studi Pendidikan Sosiologi \\ ${ }^{3}$ Dosen Program Studi Pendidikan Sosiologi
}

\begin{abstract}
ABSTRAK
Penelitian ini bertujuan untuk mengetahui gambaran konflik antara masyarakat yang menempati lahan hutan lindung dengan Perhutani di Kampung Sukawana Desa Karyawangi Kecamatan Parongpong Kabupaten Bandung Barat. Penelitian menggunakan pendekatan kualitatif dan metode studi kasus. Temuan penelitian adalah, faktor utama masyarakat RW 13 Kampung Sukawana menempati lahan hutan lindung karena keterbatasan ekonomi dan adanya pembiaran dari pihakpihak tertentu, adanya konflik ini disebabkan oleh alih fungsi lahan dari lahan hutan lindung menjadi lahan pemukiman, warga masyarakat semakin bertambah banyak, terdapat rumah semi permanen bahkan permanen, dan terdapat pula warung serta kandang hewan ternak.
\end{abstract}

Kata Kunci : Konflik, Masyarakat, Perhutani, Pengambilan lahan

\section{PENDAHULUAN}

Berdasarkan hasil observasi yang dilakukan oleh peneliti, di Kampung Sukawana RW 13 Desa Karyawangi Kecamatan Parongpong Kabupaten Bandung Barat terdapat lindung seluas 850 hektar yang berisi pohon pinus. Menurut pemaparan dari Pak Oma selaku ketua RW 12, pada awalnya di daerah hutan lindung tersebut bebas dari pemukiman penduduk. Lokasi hutan lindung yang berdekatan dengan perkebunan teh, membuat para pekerja kebun teh yang sudah pensiun ataupun para pekerja yang sudah keluar dari perkebunan teh mulai menempati dan mendirikan rumah di lahan kawasan hutan lindung.

Hingga saat ini berdasarkan data kependudukan setempat tahun 2013, lahan hutan lindung tersebut sudah ditempati oleh 53 kepala keluarga (KK). Selain pemukiman di lahan hutan lindung tersebut terdapat pula 25 kandang sapi, 5 warung serta pekarangan di depan rumah masingmasing. Berdasarkan observasi awal, ditemukan bahwa pada tanggal 22 Agustus 2013 berdasarkan data di kantor Desa Karyawangi Kecamatan Parongpong Kabupaten Bandung Barat terdapat perjanjian antara Perum Perhutani KPH Bandung Utara dengan masyarakat setempat terkait dengan penanganan konflik 
tenurial (Penggunaan Kawasan Tanpa ljin) yang menyebabkan masyarakat resah.

Adanya

perbedaan

kepentingan antara Perhutani dengan masyarakat memunculkan pertentangan tersendiri. Terjadinya alih fungsi lahan tersebut menimbulkan perbedaan kepentingan antara pemerintah yang berkepentingan untuk menjaga kelestarian kawasan hutan lindung dan kepentingan ekonomi masyarakat.

Ditinjau dari segi sosiologis, permasalahan tersebut merupakan konflik antara masyarakat dengan Perhutani. Dilihat dari sumber konfliknya, konflik tersebut termasuk konflik vertikal. Maftuh (2008, hlm. 29) menjelaskan bahwa konflik vertikal ialah "pertentangan antara dua pihak yang memiliki kedudukan sosial yang berbeda". Dalam penelitian ini, pertentangan terjadi antara kedudukan sosial yang berbeda yakni antara Perhutani dengan masyarakat, dimana Perhutani memiliki otoritas sehingga kedudukannya lebih tinggi daripada masyarakat. Pendapat ini sejalan dengan Maftuh (2008, hlm. 29) yang menyatakan kedudukan sosial yang berbeda diantaranya "antara yang memiliki otoritas dengan yang tidak memiliki otoritas, atau antara superordinat dengan subordinat".

\section{TEORI KONFLIK}

Setiap manusia memiliki kebutuhan yang berbeda satu sama lain atau mempunyai kebutuhan yang sama mengenai sesuatu yang jumlahnya terbatas. Pergeseran fungsi lahan dalam masyarakat karena kebutuhan ekonomi menimbulkan pertentangan atau konflik antara pihak yang berkepentingan dengan masyarakatnya itu sendiri. Sebagaimana yang dikemukakan Maftuh (2008, hlm. 1) yang mengemukakan bahwa "Konflik merupakan suatu bentuk interaksi sosial ketika dua individu mempunyai kepentingan yang berbeda dan kehilangan keharmonisan diantara mereka." Sementara itu Narwoko dan Suyanto (2007, hlm. 68) menjelaskan bahwa "konflik adalah suatu proses sosial yang berlangsung dengan melibatkan orang-orang atau kelompok-kelompok yang saling menantang dengan ancaman kekerasan".

Wirawan (2010, hlm. 8) menyebutkan beberapa sumber konflik diantaranya "keterbatasan sumber, tujuan yang berbeda, interdependensi tugas, keragaman sistem sosial, deferensiasi organisasi, ambiguitas yurisdiksi, pribadi orang, sistem imbalan yang tidak layak, komunikasi yang tidak baik dan perlakuan tidak manusiawi."

Coser membagi konflik ke dalam konflik realistis dan konflik nonrealistis. Ritzer (2011, hlm. 65) menjabarkan pengertian konflik realistis menurut Coser ialah "konflik yang terjadi karena perbedaan dan ketidaksepahaman cara pencapaian tujuan atau mengenai tujuan yang akan dicapai". Sedangkan konflik nonrealistis menurut Coser (dalam Wirawan, 2010, hlm. 59) ialah "konflik 
yang dipicu oleh kebencian atau prasangka terhadap lawan konflik yang mendorong melakukan agresi untuk mengalahkan pihak lawan".

Coser (dalam Johnson, 1986, hlm. 69) membahas pula mengenai katup penyelamat. Katup penyelamat atau safety valve ialah salah satu mekanisme khusus yang dapat dipakai untuk mempertahankan kelompok dari kemungkinan konflik sosial. Katup penyelamat membiarkan luapan permusuhan tersalur tanpa menghancurkan seluruh struktur, konflik membantu "membersihkan suasana" dalam kelompok yang sedang kacau. Coser melihat katup penyelamat berfungsi sebagai jalan ke luar yang meredakan permusuhan, yang tanpa itu hubungan-hubungan di antara pihak-pihak yang bertentangan akan semakin menajam.

\section{RESOLUSI KONFLIK}

Maftuh (2008, hlm. 56) menjelaskan lima asumsi dasar dari pendidikan resolusi konflik yakni persepsi yang positif terhadap konflik, penghargaan terhadap perbedaan, dikembangkan dalam konteks kerjasama, problem solving merupakan inti, dan pendidikan resolusi konflik sebagai program prevensi dan intervensi. Kelima asumsi tersebut disimpulkan sebagai berikut : Pertama persepsi positif terhadap konflik. Persepsi positif terhadap konflik melihat konflik sebagai sesuatu yang alami terjadi dalam masyarakat. Selama ada masyarakat pasti terdapat konflik. Maka konflik harus dilihat secara konstruktif sehingga konflik dapat dipecahkan dengan baik oleh pihak yang berkonflik. Kedua, penghargaan terhadap perbedaan. Masyarakat Indonesia merupakan masyarakat yang multikultural, sehingga asumsi dari penghargaan terhadap perbedaan harus dilaksanakan. Masyarakat harus toleran, menghargai serta menghormati perbedaan yang ada. Ketiga, dikembangkan kerjasama. Konflik dapat diselesaikan dengan kerjasama atau kompetisi, kedua hal ini menentukan suatu konflik konstruktif atau destruktif. Konflik akan konstruktif bila diselesaikan dengan kooperatif sesuai dengan asumsi pendidikan resolusi konflik yang mengembangkan kerjasama. Kerjasama diperlukan karena pihak yang berkonflik harus kooperatif dalam memecahkan masalah sehingga kedua belah pihak tidak ada yang dirugikan. Keempat, problem solving merupakan inti. Inti dari pendidikan resolusi konflik yakni pemecahan masalah (problem solving). Proses pemecahan masalah mempunyai dua bagian mendasar sebagaimana dikemukakan Weitzman dan Weitzman (dalam Maftuh, 2008, hlm. 59) yakni mendiagnosis konfik dan mengembangkan alternatif penyekesaian (solusi) terhadap masalah. Adapun tahapan dari problem solving menurut Crawford dan Bodine (dalam Maftuh, 2008, hlm. 61) yaitu : (1) manata keadaan/situasi, (2) mengumpulkan pandangan, (3) mengidentifikasi kepentingan, (4) membuat pilihan, (5) mengevaluasi pilihan dan (6) 
menghasilkan kesepakatan. Kelima, pendidikan resolusi konflik sebagai program prevensi dan intervensi. Pendidikan resolusi konfli dapat digunakan sebagai pencegahan (preventif) karena mendidik perilaku dan pemahaman akan penyebab konflik dan dapat digunakan sebagai pemecahan saat konflik terjadi (intervensi) karena mendidik siswa untuk berpikir kritis mencari alternatif solusi dari konflik.

\section{HASIL DAN PEMBAHASAN}

Masyarakat yang tinggal di lahan hutan lindung milik Perhutani bukan merupakan masyarakat setempat melainkan datang dari berbagai daerah. Mayoritas pendatang ini berasal masih dari daerah di Jawa Barat seperti Tasik Malaya, Sumedang, Sukabumi, Garut, dan lain sebagainya. Namun ada pula masyarakat yang datang dari luar Jawa Barat seperti dari Solo dan NTB. Pendatang tersebut merantau dari berbagai daerah untuk bekerja di perkebunan teh. Mereka bekerja di perkebunan teh berbagai daerah dibawah naungan PTPN VII.

Berdasarkan hasil wawancara, ada beberapa faktor yang menyebabkan masyarakat tinggal di lahan hutan lindung milik Perhutani, yaitu:

1) Keterbatasan ekonomi. Sebagian besar masyarakat yang tinggal di hutan lindung milik Perhutani adalah sebagai pensiunan karyawan Perkebunan teh.

2) Lokasi pekerjaan. Masyarakat RW 13 Kampung Sukawana mayoritas adalah pensiunan perkebunan.
Dengan uang pensiun yang kurang mencukupi, mereka harus tetap bekerja guna menghasilkan pendapatan yang lebih. Lokasi pekerjaan menjadi salah satu faktor masyarakat menempati lahan hutan lindung milik Perhutani.

3) Tidak memiliki kampung halaman. Warga masyarakat pendatang di RW 13 Kampung Sukawana tidak dapat kembali ke kampung halamannya, karena berbagai faktor. Ada warga yang tidak dapat kembali ke kampung halamannya karena rumah di kampungnya sudah dijual untuk bekal awal mereka bekerja di perkebunan teh. Adapula warga yang sudah betah tinggal di Kampung Sukawana, karena sudah puluhan tahun meninggalkan kampung halaman dan bekerja di perkebunan teh sehingga memilih tidak kembali lagi ke kampungnya.

4) Adanya budaya 'Mental Kebun'. Masyarakat disini memiliki 'mental kebun' artinya mereka selalu beranggapan kepada anakanaknya buat apa sekolah karena nanti juga pasti anak-anak akan bekerja sebagai karyawan perkebunan teh sama seperti orang tuanya.

Masyarakat RW 13 Kampung Sukawana pertama kali menempati lahan hutan lindung milik Perhutani sejak tahun 1962. Ketika pensiunan karyawan perkebunan teh pertama kali muncul. Keterbatasan ekonomi memaksa pensiunan karyawan perkebunan teh tinggal di lahan hutan 
lindung milik Perhutani. Awal mulanya hanya ada 10 rumah di lahan hutan lindung tersebut, dan bertambah menjadi 13 rumah pada tahun 1963. Pada tahun 1987 dibangun Pabrik Perkebunan Pengolahan Timbang Teh. Sekitar satu tahun pabrik sudah dibangun barulah masyarakat di perkampungan ini bertambah. Dahulu hanya ada satu RW yakni RW 12 saja yang semuanya masyarakat pekerja kebun teh, namun terjadi pemekaran wilayah karena penduduknya semakin bertambah sehingga dibagi menjadi dua RW yakni RW 12 dan RW 13 yang berlokasi di lahan.

Faktor utama penyebab konflik antara masyarakat dengan Perhutani ini mengenai pengambilan lahan. Pengambilan lahan yang dimaksud ialah dari lahan hutan lindung menjadi lahan pemukiman. Namun pihak Perhutani bertindak saat penduduk sudah banyak bahkan sudah satu RW sedangkan masyarakat tidak bisa pindah ketempat lain karena faktor ekonomi. Pada tanggal 20 Agustus 2014 terdapat perjanjian terkait konflik tenurial antara masyarakat dengan Perhutani. Perhutani melarang adanya pemukiman penduduk di lahan hutan lindung. Sementara dari pihak masyarakat keberatan dengan perjanjian tersebut. Pasalnya mereka sudah bertopang hidup di lahan hutan lindung selama puluhan tahun bahkan secara turun temurun. Pihak masyarakat pun membela diri, kenapa Perhutani baru melarang pemukiman akhir-akhir ini, mengapa tidak dari dulu ketika masyarakat hendak membangun rumah di lahan hutan lindung milik Perhutani. Ketika pemukiman sudah banyak baru ada tindakan dari Perhutani. Masyarakat tidak mampu untuk pindah ataupun mengosongkan lahan hutan lindung ini, karena mereka tidak tahu harus tinggal dimana selain disini.

Ada beberapa upaya alternatif dalam meredam konflik diantaranya jumlah masyarakat RW 13 di Kampung Sukawana yang tinggal di lahan hutan lindung milik Perhutani tidak boleh bertambah. Ada beberapa informan yakni $S R, H$, L dan $S$ yang menyebutkan bahwa masyarakat yang sudah tinggal di lahan hutan lindung diperbolehkan tetap tinggal di lahan tersebut. Masyarakat tidak bisa pindah ke tempat lain sesuai aturan dari Perhutani dikarenakan keterbatasan ekonomi.. Alternatif kedua yaitu rumah yang dibangun oleh masyarakat di lahan hutan lindung milik Perhutani harus rumah sederhana. Artinya tidak boleh ada rumah semi permanen atau bahkan rumah permanen. Meskipun demikian ada beberapa rumah semi permanen di lahan hutan lindung milik Perhutani dan mereka tidak mau untuk membongkar rumahnya menjadi rumah sederhana.

Pihak Perhutani pun sering mengontrol ke wilayah ini, apalagi ditambah ada pihak-pihak tertentu yang mengklaim bahwa wilayah ini adalah hak milik mereka sebagai hasil warisan dari orang Belanda. Masyarakat disini pun ikut membantu dalam membela Perhutani karena merasa kita semua menumpang sehingga wajib membantu. 
Berdasarkan data hasil tersebut serta penduduk hanya boleh penelitian dapat dilihat bahwa masyarakat yang tinggal di lahan hutan lindung milik Perhutani berasal dari berbagai daerah namun dengan pekerjaan yang sama yakni pensiunan perkebunan teh Bukit Unggul afdeling Sukawana.

\section{PENUTUP}

Masyarakat tinggal di lahan hutan lindung milik perhutani awalnya berasal dari pensiunan karyawan perkebunan teh Bukit Unggul afdeling Sukawana. Penyebab utama mereka tinggal di lahan hutan lindung milik perhutani adalah karena faktor ekonomi.

Benang merah permasalahan konflik adalah akibat alih fungsi lahan. Solusi sementara dilakukan dengan melarang bertambahnya penduduk di lahan hutan lindung membangun rumah sederhana atau rumah non permanen saja.

\section{REFERENSI}

BUKU

Johnson, Doyle Paul. (1986). Teori Sosiologi, Klasik dan Modern Jilid II. Jakarta: Gramedia Pustaka Utama.

Maftuh, Bunyamin. (2008). Pendidikan Resolusi Konflik. Bandung : CV Yasindo Multi Aspek

Ritzer George dan Douglas J Goodman. (2011). Teori Sosiologi Modern-Edisi Ke 6. Penyadur : Alimandan. Jakarta: Kencana.

Soekanto, Soerjono. (2006). Sosiologi Suatu Pengantar. Jakarta: Raja Grafindo Persada

Wirawan (2010). Konflik dan Manajemen Konflik. Jakarta : Salemba Humanika. 